\title{
Kikuchi-Fujimoto disease: an unusual association with acute renal failure
}

\begin{abstract}
Kikuchi-Fujimoto disease, also known as histiocytic necrotizing lymphadenitis of unknown etiopathogenesis, is a self-limited disease which frequently appears as feverish lymphadenomegaly, thus creating the need for differential diagnosis with lymphoma, systemic lupus erythematosus (SLE), infectious mononucleosis, cat-scratch disease, and toxoplasmosis with lymphonodal impairment. However, there are cases in which it may evolve with complications such as aseptic meningitis, cerebellar ataxia, and aseptic myocarditis. We are presenting a case of a 24-year-old man who had an initial picture of arthralgia, evening fever and adenomegaly. Kikuchi disease was diagnosed through lymph node biopsy with immunohistochemistry and evolves with severe systemic manifestations, such as pericarditis with cardiac tamponade, pneumonitis, hepatitis, and acute kidney failure - the latter has not been reported in literature yet. There was significant improvement of the clinical picture with prednisone.
\end{abstract}

Keywords: Kikuchi-Fujimoto disease; histiocytic necrotizing lymphadenitis; acute renal failure.

[Braz J Infect Dis 2010;14(6):621-627]@Elsevier Editora Ltda.

\section{INTRODUCTION}

Kikuchi-Fujimoto Disease (KFD), also known as histiocytic necrotizing lymphadenitis, was described in Japan, in 1972, by Kikuchi and Fujimoto ${ }^{1,2}$ simultaneously. It is a frequently selflimited entity, and for that reason it is not often diagnosed. It most usually affects women up to 30 years old. Most cases resolve within six months. ${ }^{3}$ The most common symptoms are lymphadenomegaly, fever, rash, fatigue, and arthralgia, ${ }^{3}$ but there are reports of cases with severe systemic manifestations, such as aseptic meningitis, cerebellar ataxia, and aseptic myocarditis. ${ }^{4}$ The histologic findings includes areas of coagulation necrosis with abundant karyorrhexis debris. The latter consists of different types of histiocytes, plasmocytes, monocytes, immunoblasts, and small and large lymphocytes. There is abundant predominance of T lymphocyte with prevalent $\mathrm{CD} 8+$ in relation to $\mathrm{CD} 4+.{ }^{11}$ This disease's pathogenesis is unknown, with autoimmune and viral factors implied. It is essential to establish a differential diagnosis with lymphoma, systemic lupus erythematosus (SLE), infectious mononucleosis, cat-scratch disease, and toxoplasmosis with lymphonodal impairment. ${ }^{3}$
The authors report a case with severe systemic manifestations, such as hepatosplenomegaly, pneumonia, pericardial effusion with cardiac tamponade, sepsis, and acute renal failure. The latter has not been reported in literature yet.

\section{CASE REPORT}

Male patient, 24-years-old, black, born in Piauí, coming from Bertioga, SP. He was accepted at Santa Casa de Misericórdia de Santos with a history of evening fever for 46 days at $38^{\circ} \mathrm{C}$, arthralgia in major articulations, myalgia, weight loss of $10 \mathrm{~kg}$, anemia, hepatosplenomegaly of 5 $\mathrm{cm}$ and adenomegaly of fibroelastic consistence, 1 to $2 \mathrm{~cm}$ long, in inguinal, axillary, and posterior cervical chains, as well as jaundice $+/++++$. The neck computerized tomography observed multiple neck lymph nodes of $1.5 \mathrm{~cm}$ in submentonian and posterior cervical chains. The abdominal ultrasound showed mild hepatomegaly and moderate splenomegaly. Results of the blood count were: leukocytes $53,900 \mathrm{~mm}^{3}$, platelets $131,000 / \mathrm{mm}^{3}$, red blood cell 3,47 million $/ \mathrm{mm}^{3}$, hemoglobin $7.67 \mathrm{~g} / \mathrm{dL}$, hematocrit 24.7\%, aspartate aminotransferase (AST) 1,208 U/L,
Authors

Amanda Feliciano da Silva ${ }^{1}$

Roberto Focaccia

Allan Constantino de Oliveira $^{1}$

Angelo Sementilli

Gelvana Flávio Barreto Reis $^{3}$

${ }^{1} \mathrm{MD}$, Universidade Metropolitana de Santos. ${ }^{2} \mathrm{MD}$, PhD, Professor, Universidade Metropolitana de Santos.

${ }^{3} \mathrm{MD}$, Master's Degree, Universidade Metropolitana de Santos.
Submitted on: 02/17/2010 Approved on: 06/01/2010

Correspondence to: Roberto Focaccia Avenida Higienópolis, 360 ap. 14, Higienópolis, 01238-000, São Paulo, SP, Brazil

E-mail:

focaccia@uol.com.br

We declare no conflict of interest. 
alanine aminotransferase (ALT) $844 \mathrm{U} / \mathrm{L}$, indirect bilirubin (IB): $0.38 \mathrm{mg} / \mathrm{dL}$, direct bilirubin (DB): $1.75 \mathrm{mg} / \mathrm{dL}$, total bilirubin (TB): $2.13 \mathrm{mg} / \mathrm{dL}$, gamma glutamyl transferase (GGT) $542 \mathrm{U} / \mathrm{L}$, as shown in Table 1. For the investigation of fever of infectious origin, brucellosis,

Table 1. Laboratory from the first hospitalization

\begin{tabular}{|ll|}
\hline Red blood cell & 3,470 million $/ \mathrm{mm}^{3}$ \\
\hline Hemoglobin & $7.67 \mathrm{~g} / \mathrm{dL}$ \\
\hline Hematocrit & $24.7 \%$ \\
\hline Leukocytes & $53,900 / \mathrm{mm}^{3}$ \\
\hline Platelets & $131,000 / \mathrm{mm}^{3}$ \\
\hline AST (aspartate aminotransferase) & $1,208 \mathrm{u} / \mathrm{L}$ \\
\hline ALT (alanine aminotransferase) & $844 \mathrm{u} / \mathrm{L}$ \\
\hline Total bilirubin & $2.13 \mathrm{mg} / \mathrm{dL}$ \\
\hline Direct bilirubin & $1.75 \mathrm{mg} / \mathrm{dL}$ \\
\hline Indirect bilirubin & $0.38 \mathrm{mg} / \mathrm{dL}$ \\
\hline Gamma glutamyl transferase & $542 \mathrm{U} / \mathrm{L}$ \\
\hline
\end{tabular}

leptospirosis, toxoplasmosis, HTLV1, HTLV2, and viral hepatitis types A, B, C were investigated, and ELISA method was used for all research; for mononucleosis, another two samples were collected, and the method used was Hoff and Bauer; for leishmaniasis and paracoccidioidomycosis the technique of complement fixation reaction was used; for Chagas disease, immunofluorescence was used; for cytomegalovirus, chemiluminescence was used. All results were negative. When researching HIV (human immunodeficiency virus) 1 and 2, at least two samples were collected at different times with microparticle enzyme immunoassay (MEIA), and all were negative. PPD (Purified Protein Derivative of tubercle bacilli) was non-reactive, as shown in Table 2. Lymph node biopsy revealed diffuse proliferation of histiocytic cells with mature

Table 2. Search for the infectious agent

\begin{tabular}{llc}
\hline Brucellosis & Non-reagent & Enzyme immunoassay \\
\hline Leptospirosis & Non-reagent & Enzyme immunoassay \\
\hline Toxoplasmosis & Non-reagent & Enzyme immunoassay \\
\hline HTLV-1, HTLV-2 & Non-reagent & Enzyme immunoassay \\
\hline Viral hepatitis types A, B, C & Non-reagent & Enzyme immunoassay \\
\hline Mononucleosis - two samples & Non-reagent & Monotest Hoff-Bauer \\
\hline Leishmaniasis & Non-reagent & Complement fixation reaction \\
\hline Paracoccidioidomycosis & Non-reagent & Complement fixation reaction \\
\hline Chagas disease & Non-reagent & Immunofluorescence \\
\hline Cytomegalovirus & Non-reagent & Chemiluminescence \\
\hline HIV 1 e 2 - two samples with a 3-month-interval & Non-reagent & Microparticle enzyme immunoassay \\
\hline PPD & Non-reactive & \\
\hline
\end{tabular}

lymphocytes. Several histiocytic cells showed enlarged nucleus with prominent nucleolus. The diagnosis of Hodgkin's lymphoma was excluded by the absence of Reed-Steinberg cell and by immunohistochemical examination (negativity of immunoexpression for marker CD30).

The histochemical exam of the lymphonodal tissue has demonstrated an interfollicular histiocytic and lymphoid is coherent with the proliferative phase of histiocytic necrotizing lymphadenitis, also known as Kikuchi-Fujimoto disease. The material was assessed by another pathologist, who confirmed the diagnosis of Kikuchi-Fujimoto disease through an immunohistochemical analysis. Besides the polyclonal aspect, the finding of lymphocyte CD30 expression was discovered to be occasional, with B lymphocyte (CD20) islands, preserved lymphoid follicle, and a number of histiocytes (CD68) diffusely distributed (Table 3 and Figures 1 and 2).

In the evolution, the patient showed intense dyspnea, and the echocardiogram revealed pericardial effusion with cardiac tamponade, which was drained and underwent to a biopsy. The anatomopathological examination resulted in a mild, non-specific, chronic pericarditis. With remission of symptoms, the patient was discharged from hospital three months later. After 75 days, he was readmitted into the Service of Infectious Diseases, presenting pneumonia and evolution of fever to sepsis. He had fever, hepatosplenomegaly, arthralgia, hyperchromic macula-papular skin lesions, blurred vision, oral candidiasis, and inguinal and axillary adenomegaly of fibroelastic consistence, fixed and tenderness. Blood count: leukocytes $18,000 \mathrm{~mm}^{3}$, platelets $277,000 / \mathrm{mm}^{3}$, hemoglobin $11.6 \mathrm{~g} / \mathrm{dL}$, hematocrit $35 \%$, red blood cell 4,95 million $/ \mathrm{mm}^{3}$. Lactic dehydrogenase (LDH) $942 \mathrm{U} / \mathrm{L}$, alkaline phosphatase (AP) 72 UI, AST 107 U/L, ALT 69 U/L, GGT 33 U/L, creatinine $0.8 \mathrm{mg} / \mathrm{dL}$, BUN $24 \mathrm{mg} / \mathrm{dL}$, potassium (K) $4.9 \mathrm{mEq} / \mathrm{L}$, sodium $(\mathrm{Na}) 140 \mathrm{mEq} / \mathrm{L}$, albumin $3.2 \mathrm{~g} / \mathrm{dL}$, as shown in Table 4 . In the investigation of autoimmune proliferation with focuses of reactive pattern apoptosis, which 
Table 3. Results of the examinations through lymph node tissue histochemistry

\begin{tabular}{lc}
\hline Antigen & \multicolumn{1}{c}{ Result } \\
\hline $\begin{array}{l}\text { Antigen ki-67 } \\
\text { (clone MIB-1) }\end{array}$ & $\begin{array}{c}\text { Positive (++/++) } \\
\text { in follicular areas }\end{array}$ \\
\hline CD30 (clone Ber-H2) & Negative \\
\hline $\begin{array}{l}\text { Epithelial membrane } \\
\text { antigen (EMA) }\end{array}$ & $\begin{array}{c}\text { Focal positive in } \\
\text { permeate [R1] plasmocyte }\end{array}$ \\
\hline $\begin{array}{l}\text { Leukocyte common } \\
\text { antigen (LCA-CD45) }\end{array}$ & Positive \\
\hline $\begin{array}{l}\text { CD15 (granulocyte } \\
\text { associated antigen) }\end{array}$ & Negative \\
\hline Oncoprotein Bcl-2 & Negative follicular areas \\
\hline $\begin{array}{l}\text { CD3 (monoclonal antibody - } \\
\text { T lymphocyte marker) }\end{array}$ & $\begin{array}{c}\text { Positive interfollicular } \\
\text { lymphoid cells }\end{array}$ \\
\hline $\begin{array}{l}\text { CD20 (monoclonal antibody } \\
\text { L26 - B lymphocyte marker) }\end{array}$ & $\begin{array}{c}\text { Positive in follicular } \\
\text { lymphoid cells }\end{array}$ \\
\hline
\end{tabular}

Figure 1: Lymph node slice presenting preserved lymphoid follicle, surrounded by numerous histiocytes. (HE stain, 100X).

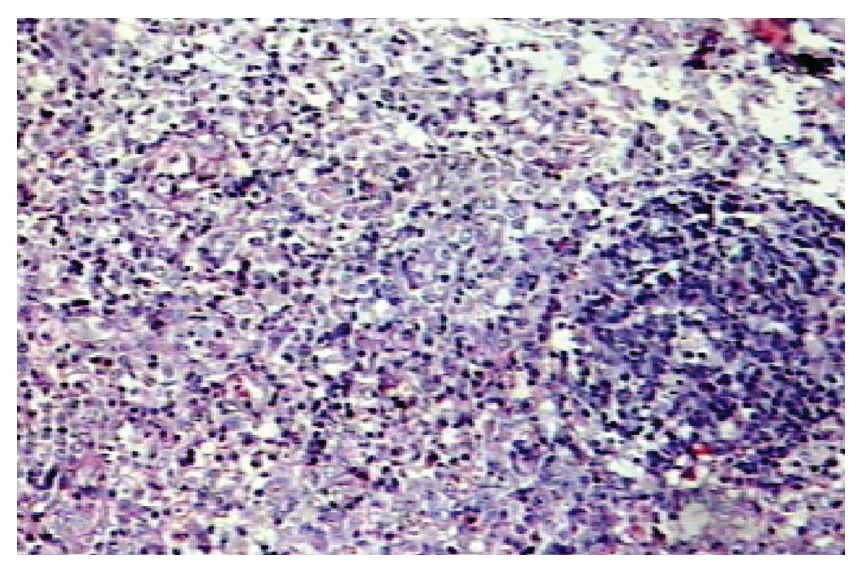

Figure 2: Presence of numerous histiocyte cells, with vesicular nucleus, and some degenerating cells. Small and mediumsized lymphocytes can also be observed. (HE stain, 400X).

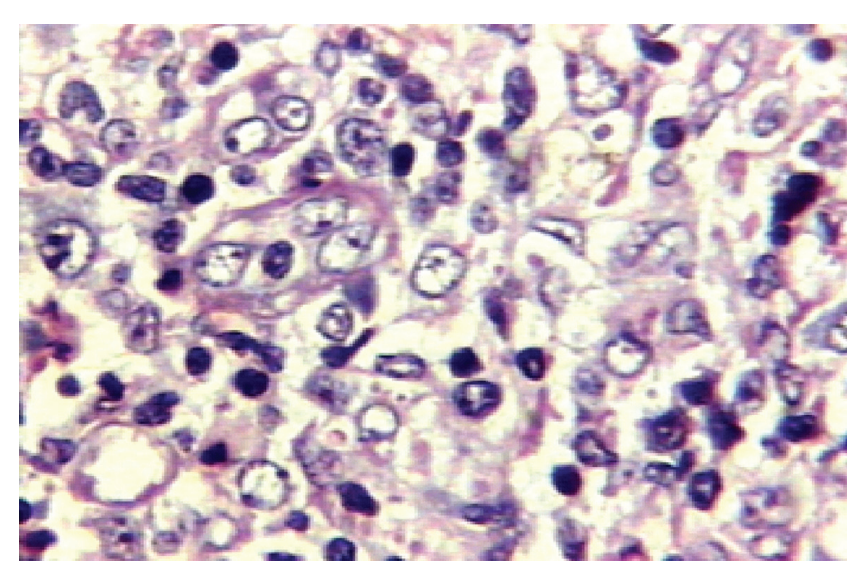

disease, antinuclear factor (ANF), anti-native DNA, antiSSA/Ro, RNP - antigen extracted from nucleus, anti-SM (anti-smith), anti-endomysial, SSB (La) - antigen extracted from nucleus; all were non-reactive. Total complement $385 \mathrm{mg} / \mathrm{dL}$, complement C3 $175 \mathrm{mg} / \mathrm{dL}$, complement C4 $43.9 \mathrm{mg} / \mathrm{dL}$, as it is shown in Table 5. Cell immunity was evaluated at CD4 $=250$ cells $/ \mathrm{mm}^{3}, \mathrm{CD} 8=2,340 \mathrm{~mm}^{3}$, as shown in Table 6 . The abdominal ultrasound showed hepatosplenomegaly.

Table 4. Laboratory from the second hospitalization

\begin{tabular}{lc}
\hline Red blood cell & $4,950 \mathrm{million} / \mathrm{mm}^{3}$ \\
\hline Hemoglobin & $11.6 \mathrm{~g} / \mathrm{dL}$ \\
\hline Hematocrit & $35 \%$ \\
\hline Leukocytes & $18,000 / \mathrm{mm}^{3}$ \\
\hline Platelets & $277,000 / \mathrm{mm}^{3}$ \\
\hline LDH & $942 \mathrm{U} / \mathrm{L}$ \\
\hline AP & $72 \mathrm{UI}$ \\
\hline AST & $107 \mathrm{U} / \mathrm{L}$ \\
\hline ALT & $69 \mathrm{U} / \mathrm{L}$ \\
\hline GGT & $33 \mathrm{U} / \mathrm{L}$ \\
\hline Creatinine & $0.8 \mathrm{mg} / \mathrm{dL}$ \\
\hline BUN & $24 \mathrm{mg} / \mathrm{dL}$ \\
\hline K & $4.0 \mathrm{mEq} / \mathrm{L}$ \\
\hline Na & $140 \mathrm{mEq} / \mathrm{L}$ \\
\hline Albumin & $3.2 \mathrm{~g} / \mathrm{dL}$ \\
\hline
\end{tabular}

Table 5. Investigation of autoimmune disease

\begin{tabular}{lc}
\hline Anti-nuclear factor (ANF) & Non-reagent \\
\hline Anti-native DNA & Non-reagent \\
\hline Anti-SSA/RO & Non-reagent \\
\hline RNP - antigen extracted from nucleus & Non-reagent \\
\hline Anti-SM & Non-reagent \\
\hline Anti-endomysial & Non-reagent \\
\hline SSB $($ La) - antigen extracted from nucleus & Non-reagent \\
\hline Total complement & $385 \mathrm{mg} / \mathrm{dL}$ \\
\hline Complement C3 & $175 \mathrm{mg} / \mathrm{dL}$ \\
\hline Complement C4 & $43,9 \mathrm{mg} / \mathrm{dL}$ \\
\hline
\end{tabular}

Table 6. Evaluation of cell immunity

\begin{tabular}{cc} 
CD4 & 250 cells $/ \mathrm{mm}^{3}$ \\
\hline CD8 & 2,340 cells $/ \mathrm{mm}^{3}$
\end{tabular}


All tests were performed at Laboratório da Santa Casa de Misericórdia de Santos (Figures 3, 4 and 5).

An antibiotic therapy for lung focus was initiated with moxifloxacin (400 $\mathrm{mg} /$ day for three days), with no improvement. The patient evolved for lung focused sepsis, and the medication was changed for cefepime (4 g/day) and vancomycin (2 g/day).

Figure 3: Immunohistochemical examination. Nuclear immunoexpression in lymphoid cells from paracortical area. (CD3, 400X).

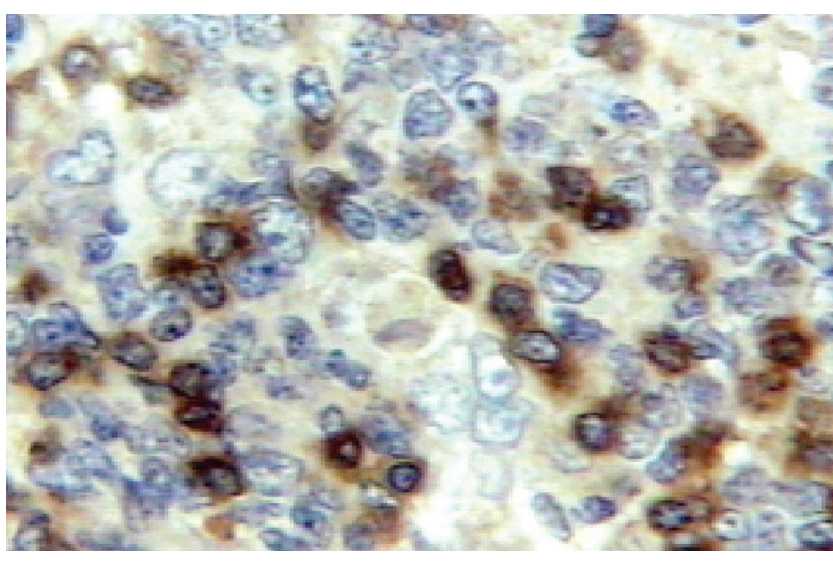

Figure 4: Immunohistochemical examination. Immunoexpression of B lymphocyte in the lymphoid follicle (CD20, 100X).

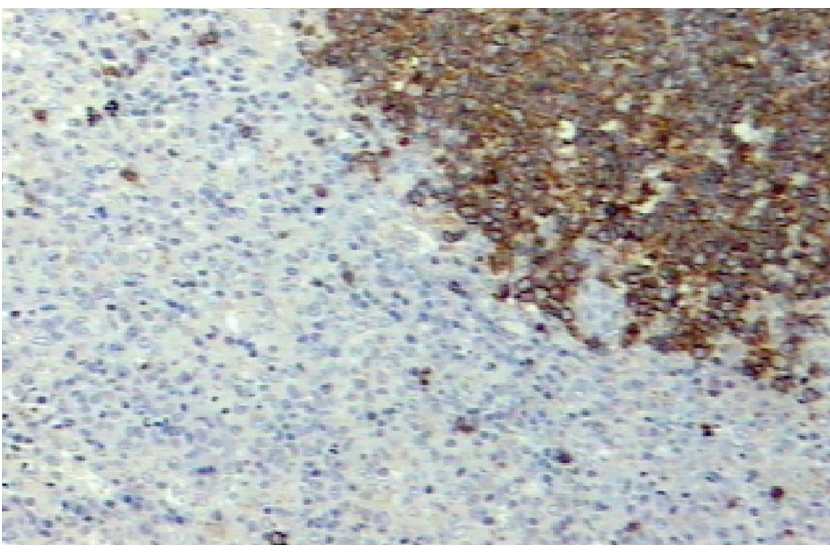

Figure 5: Lymph node immunohistochemical examination. Great expression in histiocyte cells present on the display (CD68, 400X).

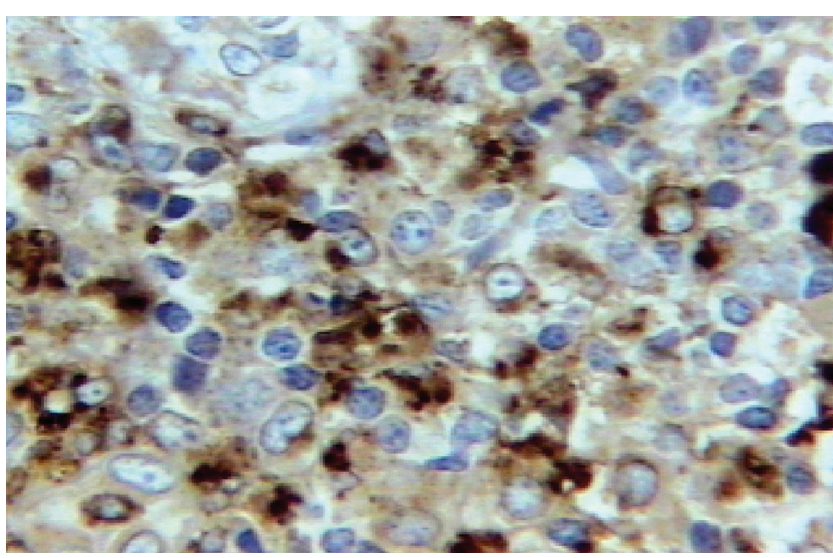

Considering Kikuchi-Fujimoto disease as the pathological basis, the use of non-hormonal anti-inflammatory piroxicam (40 mg/day for five days) was initiated. There was no response to the anti-inflammatory, and although the patient remained severely ill, renal function remained preserved (creatinine $0.8 \mathrm{mg} / \mathrm{dL}$; urea $34 \mathrm{mg} / \mathrm{dL}$ ). Due to the case's severity, a treatment with prednisone ( $60 \mathrm{mg} /$ day for 15 days) was adopted, having good clinical response. Once the corticosteroid dose started to be reducing ( $20 \mathrm{mg}$ of prednisone/day), the patient worsened and evolved to acute renal failure, with serum levels of creatinine at $72 \mathrm{mg} / \mathrm{dL} ; \mathrm{BUN} 231 \mathrm{mg} / \mathrm{dL} ; \mathrm{Na} 141 \mathrm{mEq} / \mathrm{L}$; and $\mathrm{K} 6.1 \mathrm{mEq} / \mathrm{L}$. On the ultrasound scan, the kidneys appeared to have acute parenchymatous nephropathy. Four sessions of hemodialysis were performed.

With prednisone's dose as it was previously ( $60 \mathrm{mg} /$ day), the patient had excellent improvement with a regression of the syndrome. After 64 days of outpatient treatment, he was discharged from the hospital, keeping the corticoid therapy. As he evolved, renal and liver biopsy revealed: tubular degenerative change, and mild chronic hepatic inflammatory activity, eliminating the diagnosis of autoimmune hepatitis. Currently the patient maintains proteinuria of $0.27 \mathrm{~g} / 24 \mathrm{~h}$, and therefore receives captopril (25 mg/day), and prednisone ( $20 \mathrm{mg} /$ day). The patient has had the disease inactive for three years.

\section{DISCUSSION}

Historically, it has been reported that KFD affects women more than men in a ratio of approximately four to one. ${ }^{1} \mathrm{Re}-$ cent reports seem to indicate that the female preponderance was overemphasized in the past, and that the actual ratio is closer to 1:1.5 And KFD has been reported to have occurred in a parent and a child. ${ }^{6}$

This disease's pathogenesis is still unknown. Several etiologies have been reported. Cases of KFD have been described as being associated with infections by Epstein-Barr virus, cytomegalovirus, herpes simplex type 6 and 8, HTLV-1, HIV, parvovirus type B, parainfluenza, paramyxovirus, Toxoplasma, Yersinia enterocolitica, brucellosis, the mumps virus, Mycobacterium szulgai and Bartonella henselae.

The hypothesis of a casual relation between viral infectious agents and KFD is coherent due to a raise found in the levels of interferon alpha and 2-5 oligoadenilate synthetase. ${ }^{1}$ There are also reports of raise in the serum level of interferon gamma and interleukin- 6 in patients with KFD. However, the attempts to identify a specific etiologic agent through culture, serology, polymerase chain reaction (PCR), and hybridization techniques have all failed. ${ }^{1,7} \mathrm{~A}$ strong autoimmune component of the disease, which has been observed ${ }^{2}$ and is also our case, could be related to the etiology. Thus all the cultures and serologies are negative, and through remission of the disease with high dose of corticosteroids. In the case in study, cell immune deficiency has been reported due to low counting of lymphocyte 
CD4 $\left(\mathrm{CD} 4=250\right.$ cells $\left./ \mathrm{mm}^{3}\right)$. The existence of lymphocyte and histiocyte cells suggests hyperimmune lymphadenitis reactive to several infectious, irritative, toxic, and neoplasic factors. ${ }^{2}$ A change in cell immunity (T lymphocyte) with delayed hypersensitivity to some antigens was also observed. There are reports on the association of Kikuchi-Fujimoto disease with systemic lupus erythematosus (SLE), Still's disease, Hashimoto's thyroiditis, subacute lymphocyte thyroiditis, silicone implants, hepatic transplant, ${ }^{1}$ polymyositis, and rheumatoid arthritis. ${ }^{7}$ In our case, the antibodies present in the autoimmune diseases' diagnosis were negative. What can also be discarded is lupus nephritis, since the tubular lesion seen in this patient's optical microscopy $(\mathrm{OM})$ is non-specific, and none deposits suggesting lupus nephritis, were found in the immunofluorescence, nor a glomerular lesion in the OM.

Clinical manifestations of KFD frequently occur as acute or subacute forms, which last for periods of 2 to 3 weeks. The most common form of presentation is lymphadenopathy, primary cervical ( $74 \%$ to $90 \%$ of the cases) or supraclavicular. Adenopathies typically measure less than $3 \mathrm{~cm}$ in diameter, present a firm consistency and are sometimes painful upon palpation. Generalized lymphadenopathy occurs in a minority $(5 \%)$ of cases. ${ }^{8}$

The disease courses with fever from $30 \%$ to $50 \%$ of cases, usually of low-grade, associated with symptoms of upper respiratory tract. Symptoms such as weight loss, nausea, vomiting, sore throat, and night sweat are not common, and when they occur, they are related to extranodal involvement. ${ }^{5,6,7,9}$ Recurrence of the disease is about $3 \%$ of cases in a period of 12 to 18 years after the first episode.

Because of this, long-term follow-up evaluation should be performed due to disease recurrence and to the possibility of SLE (systemic lupus erythematosus) development. ${ }^{8}$

There are atypical systemic manifestations such as panuveitis with impairment of visual acuity, ${ }^{10}$ arthritis, ${ }^{11}$ four cases of aseptic meningitis, amigdalitis ${ }^{12}$ and cryptogenic organizing pneumonia. ${ }^{13}$ Mortality is rarely found in KFD, but there have been three cases due to the disease, such as a 38-year-old woman with acute heart failure, in whose necropsy multiple focuses of cardiac necrosis were found; there has been another case of a 19-month-old child who died of febrile syndrome, and whose necropsy revealed a clinical picture compatible with extranodal and nodal KFD; ${ }^{14}$ finally, there has been a case of KFD death in a patient who had received a transplant. ${ }^{12}$

The definitive diagnosis of KFD is made through lymph node excision biopsy and histologic examination. There are several classic histologic features of KFD. The affected lymph nodes have patchy necrotizing regions (the degree of necrosis varies widely among patients), mainly in the paracortical areas. They often contain well-circumscribed areas of eosinophilic fibrinoid material with a substantial degree of karyorrhexis. Transformed lymphocytes (immunoblasts) may surround the necrotic areas, creating a characteristic mottled appearance at low magnification. Nuclear debris is evenly scattered throughout the necrotic areas and is associated with atypical mononuclear cells, which may be macrophages phagocytosing the debris. ${ }^{14}$ It has been reported that the lesional cells extended into the perinodal fibroadipose tissue. ${ }^{15}$ The histological change in KFD has been classified into three stages: an early proliferative stage, an intermediate phagocytic stage, and a full-blown post necrotic or xanthomatous stage. During the proliferative stage, CD116 and CDIIc positive histiocytes predominant are accompanied by numerous atypical lymphocytes, which are primarily CD4+ T helper cells. In contrast, CD8+ suppressor $\mathrm{T}$ lymphocytes are the most predominant cells in the postnecrotic stage. ${ }^{16}$ In a retrospective study of 1,724 lymph node biopsy samples, KFD was found in 36 cases. ${ }^{17}$

As reported in the literature, the lymph nodes immunohistochemistry were characterized by numerous CD20-positive B-cell displayed in primary and secondary reactive lymphoid follicles, often surrounded by prominent B-cell rich mantle zones. In contrast, most cells within the necrotizing foci were large CD68-positive phagocytic macrophages and plasmacytoid dendritic cells, with scattered medium to large CD3-positive T-cells, and relatively few scattered medium to large CD20-positive B-cells. ${ }^{18}$

Radiographic findings specific to KFD have not been established, and reports of KFD in the medical literature have largely focused on the disease pathology. Chest radiography should be included in the diagnostic evaluation to eliminate the possibility of malignancy or tuberculosis. CT and ultrasonography scans are common and often helpful before obtaining a biopsy specimen. Ultrasonography scan frequently shows lymph nodes with a hypoechoic center and a hyperechoic rim..$^{11,12}$ CT findings generally mimic those of lymphoma; however, lymph nodes in patients with KFD are not as large as those in patients with lymphoma. There are no specific assays available to confirm the diagnosis of KFD. ${ }^{14}$

The radiographic diagnosis of KFD is broad and includes Hodgkin and non-Hodgkin disease, metastatic tumor, tuberculosis, nontuberculous mycobacterial infection, SLE, human immunodeficiency virus infection, infectious mononucleosis, cat-scratch disease, mucocutaneous lymph node syndrome (Kawasaki disease), and toxoplasmosis. In one series, 29\% of patients with KFD were initially misdiagnosed as having Hodgkin or non-Hodgkin disease. ${ }^{14}$

The differential diagnosis of a slow-growing neck mass is broad and includes malignant lymphoma, systemic lupus erythematosus (SLE), Hodgkin disease, toxoplasmosis, metastatic carcinoma, infectious mononucleosis, acquired immunodeficiency syndrome, cat-scratch disease, and angioimmunoblastic lymphadenopathy. ${ }^{14}$ KFD is different from lymphoma, especially in early stages, in which there are few necrosis zones and also immunoblasts originating among nuclear debris. Immunophenotyping constitutes a process valuable for distinguishing these two entities. ${ }^{19}$ 
There are some characteristics, such as gender and age, as well as histological alterations, that KFD and SLE have in common, some authors considering the former to be a lupus-like syndrome. It has been proposed that KFD is a manifestation of, or evolves to, SLE, justifying the surveillance of KFD patients using immunological studies such as ANF (antinuclear factor) testing. Patients can present positivity for ANF, anti ribonucleoprotein, anti-DNA and lupus anticoagulant. Other autoimmune conditions, such as antiphospholipid antibody syndrome, polymyositis, Still's disease, uveitis, scleroderma, thyroiditis, pulmonary hemorrhage and interstitial lung disease, can be associated with KFD. ${ }^{8}$

KFD and lymph nodal tuberculosis (LTB) are commonly mistaken. There are cases in the literature described with LTB diagnosis before the anatomopathological examination. ${ }^{12}$ There is also another case in which the patient received treatment for Wegener's granulomatosis. ${ }^{8}$ That is why the etiologic diagnosis is important, in order to avoid long and expensive treatment.

There is no effective treatment. Patients with more severe or persistent symptoms have been treated with corticosteroids. ${ }^{8}$ In our case, corticoid therapy with prednisone has had significant importance, for it revealed transitory relation with symptom reduction. With the remission of prednisone, the patient has shown a worse KFD picture and has presented an atypical systemic manifestation, which has not been reported in the literature for this disease: acute kidney failure (AKF). Because suspicion that AKF had relation to the disease was arisen, immunosuppresant doses were retaken, thus immediately improving KFD and leading to remission of nephropathy, revealing it to be dependent on prednisone dosage. The new attempt of reducing the doses of corticoid therapy had success. For the authors, remains the impression that the AKF appeared in a moment when KFD had stronger symptoms and when adequate treatment of Kikuchi disease reduced kidney failure. All this leads us to thinking that besides turbidity, arthralgia, myalgia, pericarditis, and hepatitis, acute kidney failure is another manifestation of the disease.

In conclusion, KFD usually occurs as acute or subacute, with auto limited evolution; an important differential diagnosis must be done with lymphoma, which was the main differential diagnosis in the case reported. Although it might still be related to autoimmune disease, so far there has not been a report of renal failure in literature. With that being said, nephropathy associated with HIV can be discarded, since the patient is HIV-negative and no typical lesion has been identified. Despite the patient having presented a series of irregularities during the disease's evolution, the possibility of interstitial nephritis induced by drugs has not been confirmed, since that was not evident in the renal biopsy. However, the patient's lesion was nonspecific, and although it was atypical, it could have been induced by drugs, by any irregularity, or it could even have resulted from Kikuchi-Fujimoto disease itself. The disease induced by drugs usually evolves in a benign way, with extranodal impairment and severe systemic manifestations, which were found in our patient. For the cases in which there is no auto limited evolution, it may be necessary to have corticoid therapy in immunosuppresant dosage, depending on how severe it is. Such strategy was successfully adopted in the case under study.

\section{REFERENCES}

1. Kikuchi M. Lymphadenitis showing focal reticulum cell hyperplasia with nuclear debris and phagocytes: a clinicopathological study Acta Hematol Jpn. 1972; 35:37980.

2. Fujimoto Y, Kojima Y, Yamaguchi K. Cervical subacute necrtotizing lymphadenitis. Naika 1972; 30: 920-7.

3. Kucukardali Y, Solmazgul E, Kunter E et al.Kikuchi-Fujimoto Disease: analysis of 244 cases. Clin Rheumatol. 2007; 26(1):50-4.

4. Calvo Romero JM. Enfermedad de Kikuchi-Fujimoto (linfadenitis necrotizante histiocitaria). Rev Clin Esp 2002; 202:94-95.

5. Yegneswaran B, Jain V. Self limited disorder in a young female with fever, abdominal pain and lymphadenopathy. Case J 2009; 2:9318.

6. Ifeacho S, Aung T, Akinsola M. Kikuchi-Fujimoto Disease: A case report and review of the literature. Cases Journal 2008, 1:187.

7. Gómez García AM, Martínez Hurtado E, Ruiz Ribera I. Enfermedad de Kikuchi-Fujimoto asociada a infección por virus de la parotiditis: A propósito de 1 caso. An. Med. Interna (Madrid).2004; 21(3): 43-49.

8. Xavier, RG, Silva DR, Keiserman MW, Lopes, MFT. Doença de Kikuchi-Fujimoto. J Bras Pneumol. 2008; 34 (12):1074-1078

9. Bosch X, Guilabert A, Miquel R, Campo E. Enigmatic Kikuchi-Fujimoto Disease. A Comprehensive Review. Am J Clin Pathol 2004; 122:141-152.

10. Pérez Álvarez MJ, Moreno López M. Panuveítis como posible manifestación oftalmológica de la enfermedad de Kikuchi-Fujimoto. Arch Soc Esp Oftalmol. 2005; 80(1):41-44.

11. Douglas M, Bradbury R, Kannangara $S$ et al. Arthritis as an unusual manifestation of Kikuchi-Fujimoto disease. Rheumatology (Oxford). 2003; 42(8):1010-2.

12. Patricio Gac E, Patricio Cabané T, Carmen Franco S et al Tumor cervical por enfermedad de Kikuchi. Una entidad clínica a la que no estamos habituados. Caso clínico. Rev Méd Chile 2008; 136: 209-216.

13. Hua F, Zhu L. Kikuchi Fujimoto disease associated with cryptogenic organizing pneumonia: case report and literature review. BMC Infectious Diseases 2010; 10:64.

14. Archibald DJ, Carlson ML, Gustafson RO. Kikuchi-Fujimoto Disease in a 30-Year-Old Caucasian Female. International Journal of Otolaryngology. 2009, 4 pages, doi:10.1155/2009/901537.

15. Pilichowska M, Pinkus JL, Pinkus GS. Histiocytic Necrotizing Lymphadenitis (Kikuchi-Fujimoto Disease)Lesional Cells Exhibit an Immature Dendritic Cell Phenotype. Am J Clin Pathol 2009; 131:174-182. 
16. Wang TJ, Yang YH, Lin YT, Chiang BL. Kikuchi Fujimoto in children: clinical features and disease course. J Microbiol Immunol Infect. 2004; 37:219-224.

17. Mohan A, Reddy MK, Phaneendra BV, Chandra A. Aetiology of peripheral lymphadenopathy in adults: analysis of 1724 cases seen at a tertiary care teaching hospital in southern India. Natl Med J India. 2007; 20(2):78-80.
18. Hudnall SD, Chen T, Amr S et al. Detection of Human Herpesvirus DNA in Kikuchi-Fujimoto Disease and Reactive Lymphoid Hyperplasia. Int J Clin Exp Pathol. 2008; 1(4):362-368.

19. Gonçalves M, Silva G, Barros A et al. Doença de Kikuchi-Fujimoto e Lúpus Eritematoso sistêmico.Revista da Sociedade Portuguesa de Medicina Interna. 2009; (2)112. 